\title{
STUDENTS OF SECONDARY SCHOOLS OF UST-MEDVEDITSKY DISTRICT DURING THE ANTI-BOLSHEVIK REVOLT ON THE DON RIVER IN THE SPRING-SUMMER OF 1918
}

\author{
Svetlana Yu. Grechko \\ Volgograd State University, Gymnasium no. 9 (Volgograd), Volgograd, Russian Federation
}

\begin{abstract}
The article is devoted to a little-known episode in the history of the Civil War on the Don river - the participation of students of secondary schools of Ust-Medveditsky District of the Don Cossacks in the anti-Bolshevik revolt in the spring and summer of 1918. On the basis of the analysis of memories and periodical press, the author shows the role of students in the resistance to the Soviet regime in the early period of the Civil War.

The author draws our attention to the social composition of students and their relation to the Soviet regime, established in Ust-Medveditsky district in January 1918. Pupils of Ust-Medveditskaya gymnasium, dissatisfied with the resignation of the Director, organized the attack on the representative of local authorities. After the illegal assassination of one of the organizers, the teens joined the rebels of the Cossack villages of Ust-Medveditsky District. In spring of 1918 they joined the partisans and fought against the Red Army. Disorganization among the local Cossacks led to the collapse of the detachment and death of some participants. The population of the district praised the courage of fighting teenagers. The memory of the fallen defenders of the native land was immortalized in the works of Don writers.

Based on the analysis of military-political situation in the district, the author dwells upon the functioning of educational institutions in spring and summer of 1918. They collected donations to help the front.

In conclusion, the author points out that young people at the expense of their own lives pushed the adult population to take action.
\end{abstract}

Key words: national education, students, secondary schools, Ust-Medveditsky district, anti-Bolshevik revolt, Civil War on the Don river.

УДК 94(470+571)“1918”

Дата поступления статьи: 03.03.2016

ББК 63.3(2)612-414.8

Дата принятия статьи: 25.05.2016

\section{УЧЕНИКИ СРЕДНИХ УЧЕБНЫХ ЗАВЕДЕНИЙ УСТЬ-МЕДВЕДИЦКОГО ОКРУГА \\ В АНТИБОЛЬШЕВИСТСКОМ ВОССТАНИИ \\ НА ДОНУ ВЕСНОЙ - ЛЕТОМ 1918 ГОДА}

\section{Светлана Юрьевна Гречко}

Волгоградский государственный университет, МОУ гимназия № 9, г. Волгоград, Российская Федерация

Аннотация. Статья посвящена участию учеников средних учебных заведений Усть-Медведицкого округа в антибольшевистском восстании весной - летом 1918 года. На основе анализа военно-политической обстановки в округе показана роль учебных заведений в сопротивлении советской власти в период начала Гражданской войны. Рассмотрено формирование партизанского отряда, состоящего из подростков, его участие в боевых действиях.

Ключевые слова: народное образование, гимназисты, средние учебные заведения, Усть-Медведицкий округ, антибольшевистское восстание, Гражданская война на Дону. 


\section{ОТЕЧЕСТВЕННАЯ ИСТОРИЯ}

Политическая обстановка в России после революции 1917 г. и приход к власти большевиков вызвали брожение среди населения страны. Активными участниками событий были молодые люди, вынужденные принимать одну из сторон в разгорающейся Гражданской войне. Часть молодежи гордилась своей революционностью и встречала ее с восторгом, остальные - затаились, выжидали [16, с. 83]. Мемуары современников свидетельствуют о массовом участии подростков в во3расте 15-17 лет в боевых столкновениях на стороне и Красной, и Белой армий $[6 ; 8 ; 16]$.

Осенью 1917 г. студенты, гимназисты и реалисты Новочеркасска стали активными участниками боев за Ростов в составе добровольческих отрядов М.В. Алексеева. Ядро партизанского отряда В.М. Чернецова также составляла молодежь, юноши от 16 до 20 лет, которых объединяла жажда подвига и осознание своей значимости для защиты родного края $[2$, с. 123,170$]$. Гибель подростков в первых сражениях Гражданской войны на Дону привела к массовой мобилизации взрослого населения в Добровольческую армию.

Подобные события происходили в УстьМедведицком округе Области Войска Донского весной - летом 1918 г., когда он стал пограничной территорией между красным Царицыном и белым Югом, одним из центров антибольшевистского восстания. Ученики казачьих средних учебных заведений, воспитанные в духе любви и сопричастности к Отечеству, уважения истории и традиций родного края выступили защитниками дореволюционных порядков.

Участниками восстания были воспитанники Усть-Медведицкой мужской гимназии, реального, духовного училищ, учительской семинарии. К 1917 г. в реальном училище обучалось более 500 подростков, среди которых преобладали дети рядового казачества, воспитываемые за счет войскового бюджета и пособий благотворительных обществ, а также иногороднее население округа [29, л. 106-106 об.].

В Усть-Медведицкой мужской гимназии, открытой на личные средства предводителя дворянства Усть-Медведицкого округа П.И. Короткова, обучались преимущественно дети зажиточных и состоятельных казаков. Плата за обучение составляла 100 руб. в год, что было в 3 раза выше, чем в реальном училище [24, л. 15-15 об.]. По воспоминаниям современников, «домашнее и гимназическое воспитание создало то почти открытое антисоветское настроение, которое росло в гимназии в старших классах» $[32$, л. 10]. Около 80 \% гимназистов происходили из семей, настроенных против большевиков.

Роль молодежи в антибольшевистском восстании весной - летом 1918 г. в Усть-Медведицком округе отражена в мемуарах выпускников, будущих белогвардейцев-эмигрантов:гимназиста В. Сычева, реалистов П. Ветрова и Н. Келина. Кроме того, непосредственными участниками событий были известные донские писатели Ф.Д. Крюков, Р. Кумов, С.Я. Арефин, которые в литературной форме описали роль подростков в первых боевых действиях против Красной армии.

К началу 1918 г. население Усть-Медведицкого округа раскололось на три лагеря. Старики станиц и хуторов, интеллигенция были сторонниками старых порядков, не признали власти большевиков. Прибывший с фронта Усть-Медведицкий 20-й Донской казачий полк, «почти целиком разложенный большевистским ядом» $[32$, л. 1], иногороднее население, солдаты и матросы из Царицына и слободы Михайловки требовали учреждения в станице военно-революционного комитета. Некоторые станичники выжидали, чтобы примкнуть к победившей стороне. Единственные сведения о политической ситуации в стране приходили из Царицына и Михайловки, связь с югом и Новочеркасском отсутствовала.

21 января 1918 г. в станице Усть-Медведицкой Ф.К. Мироновым был учрежден военно-революционный комитет. Его председателем стал коренной житель станицы сотник С.Я. Рожков, «человек полуинтеллигентный, выгнанный за громкое поведение и плохие успехи из 4 класса Усть-Медведицкого реального училища» [32, л. 3 об.]. Родственник С.Я. Рожкова, будущий белогвардеец Н. Келин, был поражен его преображением в новой должности: «Это был уже не прежний щупленький реалист, а человек, чувствующий себя на своем месте, отягченный властью и знающий себе цену» [9, с. 39].

С утверждением советской власти в окружной станице прекращаются школьные ве- 
чера, спектакли, концерты, вместо них - беспрерывные собрания и митинги казаков [32, л. 4]. Среди новых порядков особое негодование молодежи вызвало закрытие Усть-Медведицкой газеты «Север Дона», взамен которой выпускался журнал «Муравей», содержащий преимущественно высказывания советских вождей и большевистские лозунги.

Первые сведения о состоянии дел на юге России пришли в станицу в феврале 1918 года. Слухи о готовящемся восстании оказали воздействие на гимназистов «как более восприимчивую, более горячую и нетерпеливую» часть населения станицы [32, л. 9 об.].

В 1918 г. Усть-Медведицкая мужская гимназия помещалась в двух частных домах, в одном учились 1-5 классы, во втором - 68 классы. По выражению В. Сычева, второе здание гимназии стало «антибольшевистским гнездом» [32, л. 11 об.]. Учащиеся имели много знакомых и родственников с различными политическим взглядами, прислушивались к тому, что шепотом говорили в кругу семьи, однако начать открытую борьбу не решались. Представители советской власти подозревали, какие настроения преобладают в гимназии, поэтому было принято решение о досрочном роспуске учеников на летние каникулы.

В делопроизводственных документах Усть-Медведицкого реального училища прослеживается, как после установления советской власти и введения нового календаря 26 января 1918 г. учебные заведения продолжали пользоваться старым исчислением. Так, в протоколе педагогического совета от 22 февраля 1918 г. цитировалось отношение военнореволюционного комитета от 5 марта 1918 г. о необходимости досрочного прекращения учебных занятий в связи с приближающимся острым продовольственным кризисом 1 апреля (17 марта) по новому стилю [29, л. 79].

Увольнение директора Усть-Медведицкой гимназии П.И. Короткова по обвинению в распространении монархических взглядов подтолкнуло учащихся к началу открытых действий. Одним из инициаторов стал племянник застрелившегося атамана А.М. Каледина, ученик 7 класса - Петр Каледин [11, с. 10]. Недовольные отставкой директора, в личной беседе с С.Я. Рожковым ученики вели себя вульгарно и грубо: «как извозчику стали ба- рабанить в стекла окон и подавать руками знаки» [32, л. 11 об.]. На выходе вслед председателю последовал крик воспитанника 8-го класса М. Глибездина: «Вы дождетесь от нас положенного, мы еще вас ухлопаем». На это председатель ответил: «Что ж стреляйте, хоть сейчас» [32, л. 22 об.]. Преподаватели в это время находились в здании гимназии, однако никто в разговор не вмешался.

Так за один день из гимназистов сформировалась кучка заговорщиков во главе с «энергичным, умным, отлично владеющим собой» П. Калединым в составе 7 человек (учеников 7-8 классов). На его квартире обсуждались происходящие события, было принято решение в случае репрессий искать спасения в станице Усть-Хоперской и хуторе Большом [32, л. 2525 об.]. Там под руководством войскового старшины А.В. Голубинцева шла подготовка к открытому сопротивлению новой власти. Однако в течение последующих дней в гимназии было спокойно. Известие о досрочном окончании учебного года и переводе в следующий класс по годовым отметкам заставляло учеников серьезно заняться уроками.

Антибольшевистские настроения распространились и среди реалистов. По воспоминаниям П. Ветрова, во время пребывания в Усть-Медведицкой Ф.К. Миронова, когда большевики пьянствовали, мальчишки-реалисты «крали винтовки и патроны и переправляли их в Усть-Хоперскую» [4, с. 17].

Гимназисты-заговорщики решили терроризировать военно-революционный комитет, организовать убийства должностных лиц, первым наметили председателя С.Я. Рожкова. Нашлось оружие - два револьвера браунинга, один из которых принадлежал П. Каледину [32, л. 31-31 об.]. С 22 марта подростки тщательно следили за С. Рожковым, и 6 апреля 1918 г., когда он ночью возвращался домой, гимназист 7-го класса Е. Подольский выстрелил большевику в затылок [32, 34 об.-36]. Пуля прошла насквозь, председатель остался жив, лишившись возможности говорить. Опознать нападавшего помогла ученица УстьМедведицкой женской гимназии Е. Городецкая, по слухам, находившаяся с председателем в близких отношениях. Гимназист был арестован и помещен в одиночную камеру Усть-Медведицкой тюрьмы. 
По делу Е. Подольского в станицу УстьМедведицкую прибыл следователь, который устроил допрос всем гимназистам. Несмотря на серьезность случившегося, в гимназии царило веселье, разносились песни. Старшеклассники вывесили в холле портреты императоров Николая I, Александра II и Александра III [32, л. 46-47 об.].

Следователь не смог собрать доказательств вины Е. Подольского в покушении, поэтому дело было передано в народный суд граждан Усть-Медведицкой станицы. 21 апреля 1918 г. гимназиста допросил начальник отряда красногвардейцев Горячих. Он требовал признания вины и после избиения подростка выстрелил ему в голову. Однако об убийстве никому не сообщили [32, л. 56-56 об.].

Надзиратель тюрьмы оповестил мать погибшего, новости быстро распространились среди станичников. Образ убитого юноши стал для учащихся символом борьбы за восстановление прежних порядков. По хуторам поползли слухи, что большевики «растерзали буквально на куски» подростка [9, с. 40]. В Усть-Медведицкой начались поголовные аресты. Офицеры, часть гимназистов и реалистов покинули окружную станицу [4, с. 17]. На похороны Е. Подольского 25 апреля собралось «небывалое стечение народа» [32, л. 58]. Для охраны порядка присутствовал весь отряд красногвардейцев.

В ночь с 26 на 27 апреля в хуторе Большом Усть-Хоперской станицы в здании местного приходского училища собрался Чрезвычайный съезд хуторов и станиц Усть-Медведицкого округа, который постановил «не подчиняться существующей советской власти и объявить восстание с целью изгнания Красной гвардии из пределов округа и восстановления казачьей власти». Командующим освободительными войсками вольных хуторов и станиц Усть-Медведицкого округа был назначен А.В. Голубинцев $[5$, с. 270]. Они захватили станицу Усть-Медведицкую, где началась мобилизация. По воспоминаниям В. Сычева, за два дня в формирующийся партизанский отряд есаула Г.И. Алексеева (ранее служившего в 32-м Донском полку) добровольцами записалось 63 человека «исключительно гимназистов, реалистов, семинаристов и других учащихся» $[32$, л. 60]. Самому молодому - Косте Чудину было 15 лет.
В первый же день в партизаны записался ученик 1-го класса Усть-Медведицкой учительской семинарии казак Распопинской станицы С.Я. Зерщиков, которому на тот момент не исполнилось 17 лет. Перед партизанами выступил А.В. Голубинцев, добровольцам выдали старые берданки и разделили на маленькие группы [1, с. 4]. Отряд Сергея состоял из 25 реалистов и семинаристов. Подъесаулом Бабкиным был сформирован из местной учащейся молодежи еще один отряд в 100 человек [5, с. 276-277].

Основное население станицы Усть-Медведицкой мобилизовалось медленно, выжидали дальнейших событий, прояснения обстановки. Формирующийся Усть-Медведицкий полк из 12 конных и 2 пеших сотен был составлен из «элемента, склонного к ведению войны митингами и делегациями» [3, с. 208]. В большинстве станиц создавались силы самообороны. Таким образом, антибольшевистское восстание поддерживалось только опытными офицерами, учащейся молодежью, авторитетом стариков, открыто выступавшими против советской власти.

Во время преследования красных был отбит обоз с награбленным монастырским имуществом, которое возвратили Усть-Медведицкому Преображенскому женскому монастырю. В благодарность монахини приготовили каждому партизану белую гимнастерку с синим треугольником на левом рукаве, на котором был белый вышитый череп, две скрещенные кости и по углам треугольника три белых буквы - APO [4, с. 17]. Вероятно, этот знак стал символом Усть-Медведицкого партизанского отряда.

Атмосферу, царившую среди подростков в это время, передал один из руководителей восстания П.А. Скачков: «Воодушевленная учащаяся молодежь шла в бой, вооруженная одними палками, и доставала себе оружие у красных» [30, с. 105-106]. Алексеевский партизанский отряд с пением марша ходил за станицу на обучение, резко выделяясь среди общего угнетенного состояния [30, с. 107].

Станица Усть-Медведицкая превратилась в опорный пункт, который несколько раз переходил от партизан к красногвардейцам во главе с Ф.К. Мироновым. В мае 1918 г. алексеевский отряд из учащейся молодежи вел 
наступление составом 60 чел., из которых 23 чел. имели винтовки и по 5-6 патрон, все остальные - только шашки и плеть. Партизанам помогла 4,5 дюймовая пушка, доставленная из станицы Гундоровской, и вооруженный конный отряд прославленного героя Первой мировой войны, сотника К. Крючкова [32, л. 61 об.-62]. Победа подействовала на население, на следующий день отряд возрос до 110 человек. Через два дня сформировался полк в 230 чел., группа велосипедистов из 18 чел. и конный отряд из 55 чел. [32, л. 64].

26 мая 1918 г. принято постановление № 25 Совета вольных хуторов и станиц УстьМедведицкого округа, в котором объявлялась мобилизация во всех хуторах, находящихся в районе освободительных войск, не позднее 1 июня. Те хутора, которые не исполняли распоряжение, объявлялись врагами казачества, население подлежало разоружению [27, с. 2]. В хуторах и станицах Усть-Медведицкого округа оставалось много сторонников большевизма, о чем предупреждала восстановленная газета «Север Дона». В станице Клетской большевики ушли в подполье, своих взглядов не скрывал только школьный учитель, который, «подобрав полы, с сияющим лицом бегал по красным дворам, извещая большевиков о близости своих» $[28$, с. $1-2]$.

12 июня в станице Усть-Медведицкой открылся съезд представителей Усть-Медведицкого округа, на который собралось 57 человек из 11 станиц. Главная задача съезда создание «твердой власти» в округе [22, с. 2 ; 23 , с. 3-4]. В одном из постановлений было принято решение увековечить память защитников округа от советской власти, в честь которых мужская гимназия получила официальное название: «Усть-Медведицкая окружная гимназия имени павших за освобождение округа». С этого времени детей убитых и раненых казаков решили обучать бесплатно.

На съезде обратили внимание на заслуги перед казачеством в деле воспитания и формирования национального самосознания донского поэта Ф.Д. Крюкова, которого утвердили в должности нового директора гимназии. Для увековечивания памяти погибших на самой высокой точке горного кряжа вблизи станицы Усть-Медведицкой, называемого «Пирамидой», отвели две десятины земли. Здесь планировалось соорудить памятник-колонну погибшим воинам за освобождение края от советской власти [33, с. 56].

На страницах газеты «Север Дона» отразились разногласия по поводу назначения нового директора. Из опубликованного письма П.А. Скачкова к бывшему директору Усть-Медведицкой гимназии следует, что П.И. Коротков не согласился со своей отставкой. Его осудили за пассивное отношение к Советской власти, вместо того чтобы защитить своего воспитанника гимназиста Е. Подольского, он «бросил гимназию и скрылся в подполье» [31, с. 3-4]. На хуторском сборе станицы Усть-Медведицкой инспектора народных училищ И.П. Абрамова обвинили в сочувствии большевикам и активной работе при советской власти, ему предложили выехать за пределы Донской области [17, с. 2].

Летом 1918 г. учебные заведения УстьМедведицкого округа организовали сбор средств для пострадавших в военных действиях. 29 июня в здании реального училища Усть-Медведицкое музыкально-драматическое общество провело концерт для нужд освободительных войск $[18$, с. 2]. В станице Клетской учащиеся в возрасте 10-18 лет устроили спектакль в пользу «воинов спасения Дона». Для помощи сражающимся казакам было собрано 262 руб. [25, с. 2].

Активно в сборе средств участвовали женские учебные заведения. Начальница женской гимназии Е.Н. Бугаева с воспитанницами передала 3138 руб. 33 коп. на нужды больных и раненых [19, с. 2]. В пользу алексеевского партизанского отряда собрано директором Усть-Медведицкой учительской семинарии В.А. Владимировым - 25 руб., Е.Н. Бугаевой - 53 руб. 92 коп., гимназистками Белоусовой и Волновой - 16 руб. [20, с. 2]. По инициативе фельдшера В.С. Дмитриева в станице Усть-Хоперской учащимися местного высшего начального училища был собран перевязочный материал для раненых защитников Дона. Особую отзывчивость проявила семья местного купца М.М. Токарева, которая передала 1000 папирос и корзину перевязочного материала [26, с. 2].

На фронте продолжались военные столкновения. В хуторах и станицах шли беспрерывные митинги. По воспоминаниям В. Сы- 
чева в борьбе с красногвардейцами самым надежным оставался партизанский отряд Алексеева, который ставили в пример остальным казакам [32, л. 67]. «Успокаивать» митингующую станицу Усть-Медведицкую прибыл с карательным отрядом представитель Донского правительства войсковой старшина Р. Лазарев. Он расстрелял красных депутатов, прибывших от Ф.К. Миронова, провел сбор на площади, где горячо говорил о казачестве и публично выпорол на площади протестующих большевистски настроенных казаков [3, с. 224; 32, л. 71-71 об.].

Р. Лазарев решил с учениками-партизанами взять хутор Шашкин. По его приказу каждому партизану для смелости выдали по 0,5 бутылки чистого спирта из казенного винного склада. Пьяных партизан на обывательских подводах обводным порядком доставили к Шашкину. Семинарист С. Зерщиков отметил, что перед ними стояла конкретная задача отбить орудия у красных. Однако из-за донесения местной жительницы, сообщившей большевикам о готовящемся нападении, операция сорвалась. Во время боя на сторону Ф.К. Миронова перешли распопинские казаки, партизаны попали в окружение [1, с. 6].

При численности отряда 100 чел., по данным В. Сычева, партизаны потеряли 23 чел. убитыми, 11 пленными и около 50 чел. ранеными [32, л. 73 об.]. Мироновцы в этом бою потеряли убитыми 115 бойцов и 34 лошади [4, с. 18].

Под хутором Шашкин погибла девушка, сестра милосердия А.Д. Мажарова. По сведениям П. Ветрова, она была учительницей в первом приходском училище. Девушка перевязывала раненых партизан, отстреливалась до последнего патрона. Красные подвергли ее жестокому насилию, после чего убили [4, c. 17-18].

Красногвардейцы захватили 11 пленных партизан, десять мальчиков и штабс-капитана Виноградова. Пленных переписали и конвоем повели в станицу Арчединскую. Однако под выстрелами приближающегося фронта красногвардейцы завели конвой в буерак, где расстреляли $[1$, с. 9]. Несмотря на жестокую расправу, некоторые подростки выжили. Их воспоминания стали основой для литературного произведения С.Я. Арефина «В буераке».
Сергей Зерщиков вспоминал, как они лежали в лужи крови среди мертвых тел, как умирал Валериан Попов, плакал, бредил, просил унести домой [1, с. 1-12].

Выживший подъесаул Виноградов, раненый, дошел до станицы Арчединской, где местные жители выдали его большевикам [32, л. 74 об.]. Двоих подростков обнаружили пожилые казаки, которые привезли их в Арчединскую больницу, спасло их заступничество женщины-врача. У реалиста Усть-Медведицкого реального училища Г. Попова оказалось 16 штыковых и пулевых ран, у семинариста С. Зерщикова - 28 ран [1, с. 15-16]. Пострадавших переправили в окружную больницу [32, л. $75-75$ об.].

После боя у хутора Шашкин алексеевский партизанский отряд прекратил свое существование. Подростки потеряли веру в своего командира Алексеева, который бросил на поле боя сестру милосердия и партизан, уехав на санитарной повозке в Усть-Медведицкую. Встречавшие его родители требовали сведений о своих сражающихся детях-партизанах. В итоге многие лишились своих сыновей, «бывших уже в последних классах или гимназии или реального училища, или духовного или семинарии» [32, л. 76]. Адъютант Алексеева подпоручик Козлов, по словам партизан, сам прострелил себе руку в начале боя и сбежал. Оставшиеся в живых учащиеся стали выписываться из партизанского отряда и вступать в настоящие боевые полки, пришедшие с юга [32, 76-76 об.].

Трагическим событием для станицы Усть-Медведицкой стало погребение погибших подростков. Была сооружена большая пирамида с крестом «в пять человеческих ростов». Впоследствии на одной стороне высечено стихотворение Ф.Д. Крюкова, остальные три предназначались для имен убитых [4, c. 17].

После торжественного захоронения в здании Усть-Медведицкого реального училища устроили «летучий» концерт для получения средств на первую помощь раненым. В день концерта к уезжавшему Ф.Д. Крюкову обратилась квартирная хозяйка А.В. Попова с просьбой написать что-нибудь для зрителей. Душевное состояние писателя вылилось в стихотворении в прозе, названном «Ро- 
димый край», посвященном героям «братской могилы» [30, с. 109].

Во время концерта на сцене сидели 17 раненых юношей партизанского отряда. Редактор Усть-Медведицкой газеты Н. Куницын вспоминал: «В моей памяти навсегда запечатлелась темная, тихая ночь, освещенная яркими огнями зала реального училища и несшиеся с эстрады восторженные волнующие слова этой трогательной молитвы - "Родимого края". Они хватали за душу, будили в ней далекие, безвозвратно ушедшие воспоминания детства, заставляя больнее чувствовать душевную пустоту и разбитость, оставленную годом прошедших событий» [14]. Это стихотворение молодежь учила наизусть, в сотнях экземпляров его отправляли на фронт, публиковали в периодической печати [13, с. $1 ; 30$, с. 108]. На огромном деревянном кресте над братской могилой был приведен отрывок «Родимого края»: «...во дни безвременья, в годину смутную развала...». После захвата станицы Усть-Медведицкой красными 29 января 1919 г. крест срубили, надпись сорвали [30, с. 109].

Много времени на «Пирамидах» проводил другой донской писатель Р.П. Кумов, который мечтал написать большое произведение, связанное с пережитыми событиями, назвав его «Пирамиды». Автор восхищался родной природой, которая навсегда увековечила память первых жертв Гражданской войны, отдавших свои жизни «беззаветно, беспрекословно, ради долга и высокой чести» $[15$, с. 2$]$.

Осенью 1918 г. Ф.Д. Крюков выступил за создание в Усть-Медведице «культурного уголка», центром которого должна стать братская могила на «Пирамиде». Писатель отмечал: «...здесь зарыта наша скорбь и наша радость - лучшие сыны нашего края родного, юные орлы, первые поднявшиеся в неравный бой за честь его и свободу, тут нашли вечное успокоение...» [12, с. 5-6].

В сентябре 1918 г. в учебных заведениях Усть-Медведицкого округа проходили вступительные испытания. С 10 сентября начались занятия в епархиальном училище, мужской и женской гимназии, в высшем начальном мужском училище. В реальном училище в это время располагался лазарет, из-за чего экзамены были перенесены на 2 октября, учебный год - на 10 октября [21, с. 2].
Поздней осенью 1918 г. в станице УстьМедведицкой вышел сборник «Родимый край», посвященный двадцатипятилетней литературной деятельности Ф.Д. Крюкова в издательстве газеты «Север Дона». На всех экземплярах размещалась пометка: «Весь доход от продажи сборника поступает на образование стипендии имени Ф.Д. Крюкова при Усть-Медведицких средних учебных заведениях» [14]. Составители подчеркнули значение произведений Ф.Д. Крюкова для «собирания и объединения разбитой и опозоренной родины» [7, с. 326]. 10 ноября в станице УстьМедведицкой прошел торжественный концерт, где чествовали родного писателя. На сцене его поздравили члены женского общества, драматического кружка, педагоги, кооператоры, учащиеся. Казаки Усть-Медведицкого гарнизона собрали 100 руб. 22 коп. для стипендии имени Ф.Д. Крюкова в средних учебных заведениях станицы Усть-Медведицкой $[10$, c. 324]. Граждане оценили труд писателя, который глубоко чувствовал трагизм и горечь происходящих на Дону событий.

Таким образом, современники помнили и отмечали роль подростков-партизан, учеников средних учебных заведений Усть-Медведицкого округа в борьбе с большевистской властью. Это было страшное время, когда решения принимались быстро, а жизнь, как заметил Н. Келин, «не стоила стертого пятака» $[9$, с. 49]. Ужасы Гражданской войны коснулись молодежь, которая, не имея военной подготовки, ради правды и справедливости активно записывалась в партизанские отряды и рвалась в бой. Цена участия оказалась высокой, несовершеннолетние подростки были втянуты в братоубийственную войну, многие погибли, другие ушли в армию или вернулись к учебным занятиям. Описанные события в Усть-Медведицком округе веснойлетом 1918 г. свидетельствуют о масштабности участия молодежи в первых сопротивлениях новой власти, когда юношество ценой собственной жизни подталкивало казачество к активным действиям.

\section{СПИСОК ЛИТЕРАТУРЫ}

1. Арефин, С. Я. В буераке (Быль наших дней) / С. Я. Арефин. - [Б. м.], 1919. - 16 с. 
2. Бугаев, А. Очерки истории гражданской войны на Дону (февраль 1917 г. - февраль 1918 г.) / А. Бугаев. - Ростов н/Д. : [б. и.], 2010.-400 с.

3. Венков, А. В. Атаман Краснов и Донская армия. 1918 год / А. В. Венков. - М. : Вече, 2008. - 480 с.

4. Ветров, П. Алексеевский партизанский отряд / П. Ветров // Родимый край. - 1965. - № 65. C. 17-18.

5. Голубинцев, А. Русская Вандея / А. Голубинцев // Донская армия в борьбе с большевиками. - М. : Центрполиграф, 2004. - С. 252-378.

6. Дети эмиграции. Воспоминания. 1925 // Русское небо. - Электрон. текстовые дан. - Режим доступа: http://rus-sky.com/history/library/ vospominania/ (дата обращения: 25.12.2015). - Загл. с экрана.

7. Из сборника «Родимый край» // Ф.Д. Крюков. Обвал. Смуга 1917 года глазами русского писателя. - М. : АИРО-ХХІ, 2009. - С. 326.

8. Каменецкий, И. П. Учащаяся молодежь Омска в годы революционных потрясений и гражданской войны / И. П. Каменецкий, Н. П. Логинова // Сибирский торгово-экономический журнал. 2009. - № 9. - С. 113-118.

9. Келин, Н. А. Казачья Исповедь / Н. А. Келин // Келин Н. А. Казачья Исповедь. Толстой Н. Д. Жертвы Ялты. - М. : Военное издательство, 1996. C. 7-136.

10. Коновалов, М. Юбилей Ф.Д. Крюкова в станице Усть-Медведицкой / М. Коновалов // Ф.Д. Крюков. Обвал. Смуга 1917 года глазами русского писателя. - М. : АИРО-ХХІ, 2009. - С. 324-325.

11. Корягин, С. В. Каледины и другие / С. В. Корягин // Генеалогия и семейная история Донского казачества. - М. : Русаки, 2004. - Вып. 44. - 128 с.

12. Крюков, Ф. Д. Камень созидания. Впечатления и заметки / Ф. Д. Крюков // Донские ведомости. - 1918. - № 66. - С. 5-6.

13. Крюков, Ф. Д. Край родной / Ф. Д. Крюков // Донская волна. - 1918. - № 12. - С. 1.

14. Крюков, Ф. Д. Родимый край / Ф. Д. Крюков // Тихий Дон. Нерешенная загадка русской литературы XX века. - Электрон. текстовые дан. - Режим доступа: http://www.philol.msu.ru/ lex/td/?pid=012172\& oid=042 (дата обращения: 20.12.2015). - Загл. с экрана.

15. Кумов, Р. П. Стихотворение в прозе / Р. П. Кумов // Донская волна. - 1918. - № 12. - С. 2.

16. Литвинов, В. В. Дети и гражданская война в России / В. В. Литвинов // Культура народов Причерноморья. - 2012. - № 228. - С. 78-87.

17. Местная жизнь // Север Дона. - 1918. 26 июня (№ 51).

18. Местная жизнь // Север Дона. - 1918. 29 июня (№ 54).

19. Местная жизнь // Север Дона. - 1918. 12 июля (№ 63).
20. Местная жизнь // Север Дона. -1918. 20 июля (№ 70).

21. Местная жизнь // Север Дона. - 1918. 11 сент. (№ 108).

22. Окружной круг, 12 июня // Север Дона. 1918. - 13 июня (№ 41).

23. Окружной круг, 13 июня // Север Дона. 1918. - 17 июня (№ 44).

24. О преобразовании частного учебного заведения 1-го разряда, содержимого П. Коротковым в станице Усть-Медведицкой в полноправную мужскую гимназию // Российский государственный исторический архив. - Ф. 733. Департамент народного просвещения. - Оп. 168. - Д. 325.

25. По станицам и хуторам, станица Клетская // Север Дона. - 1918. - 6 июля (№ 58).

26. По станицам и хуторам, станица Усть-Хоперская // Север Дона. - 1918. - 26 июля (№ 74).

27. Постановление Совета вольных хуторов и станиц Усть-Медведицкого округа, № 25 // Север Дона. - 1918. - 27 мая (№ 29).

28. По хуторам и станицам, станица Клетская // Север Дона. - 1918. - 30 мая (№ 31).

29. Протоколы педагогического совета УстьМедведицкого реального училища, 1918 г. // Государственный архив Волгоградской области. - Ф. 106. Усть-Медведицкое реальное училище имени атамана М.И. Платова. - Оп. 1. - Д. 108.

30. Скачков, П. [Донская летопись. 1923. № 1] // Донская армия в борьбе с большевиками. - М. : Центрполиграф, 2004. - С. 105-109.

31. Скачков, П. Открытое письмо бывшему предводителю дворянства, председателю съезда мировых судей и именующему себя директором общественной Усть-Медведицкой казачьей гимназии П.И. Короткову, 18 июня 1918 г. // Север Дона. 1918. - 22 июня (№ 48).

32. Сычев, В. Роль учащейся молодежи в деле восстания в 1918 г. в Усть-Медведицком округе Донской области // Государственный архив Российской Федерации. - Ф. 5881. Коллекция отдельных документов и мемуаров эмигрантов. - Оп. 2. - Д. 672.

33. Текст важнейших постановлений, принятых съездом представителей Усть-Медведицкого округа на заседаниях 12-14 июня 1918 г. // Филипп Миронов. (Тихий Дон в 1917-1921 гг.) : док. и материалы. - М. : Междунар. фонд «Демократия», 1997. C. 56-57.

\section{REFERENCES}

1. Arefin S.Ya. V buerake (Byl nashikh dney) [In the Gully (True Story of Our Days)]. 1919.16 p.

2. Bugaev A. Ocherki istorii grazhdanskoy voyny na Donu (fevral 1917 g. - fevral 1918 g.) 
[Essays on the History of the Civil War on the Don River (February 1917 - February 1918)]. Rostov-onDon, 2010. 400 p.

3. Venkov A.V. Ataman Krasnov i Donskaya armiya. 1918 god [Ataman Krasnov and the Don Army in 1918]. Moscow, Veche Publ., 2008. 480 p.

4. Vetrov P. Alekseevskiy partizanskiy otryad [Alekseevsky Partisan Detachment]. Rodimyy kray, 1965 , no. 65 , pp. $17-18$.

5. Golubintsev A. Russkaya Vandeya [CounterRevolution in Russia]. Donskaya armiya v borbe $s$ bolshevikami [Don Army in the Fight Against the Bolsheviks]. Moscow, Tsentrpoligraf Publ., 2004, pp. 252-378.

6. Deti emigratsii. Vospominaniya. 1925 [Children in Exile. Memories. 1925]. Russkoe nebo [Russian Sky]. Available at: http://rus-sky.com/history/library/ vospominania/. (accessed December 25, 2015).

7. Iz sbornika "Rodimyy kray" [From the Collection "Motherland"]. Kryukov F.D., ed. Obval. Smuta 1917 goda glazami russkogo pisatelya [Collapse. Description of Troubles of 1917 by Russian Writer]. Moscow, AIRO-XXI Publ., 2009, p. 326.

8. Kamenetskiy I.P., Loginova N.P. Uchashchayasya molodezh Omska v gody revolyutsionnykh potryaseniy i grazhdanskoy voyny [Students of Omsk During the Revolution and Civil War]. Sibirskiy torgovoekonomicheskiy zhurnal, 2009, no. 9, pp.113-118.

9. Kelin N.A. Kazachya Ispoved [Confessions of the Cossack]. Tolstoy N.D., ed. Zhertvy Yalty [Victims of Yalta]. Moscow, Voennoe izd-vo, 1996, pp. 7-136.

10. Konovalov M. Yubiley F.D. Kryukova v stanitse Ust-Medveditskoy [Jubilee of F.D. Kryukov in the Ust-Medveditskaya Cossack Village]. Kryukov F.D., ed. Obval. Smuta 1917 goda glazami russkogo pisatelya [Collapse. Description of Troubles of 1917 by Russian Writer]. Moscow, AIRO-XXI Publ., 2009, pp. 324-225.

11. Koryagin S.V. Kalediny i drugie [The Kaledins and Others]. Genealogiya i semeynaya istoriya Donskogo kazachestva [Genealogy and Family History of Don Cossacks]. Moscow, Rusaki Publ., 2004, iss. $44.128 \mathrm{p}$.

12. Kryukov F.D. Kamen sozidaniya. Vpechatleniya i zametki [The Stone of Creation. Impressions and Notes]. Donskie vedomosti, 1918, no. 66 , pp. 5-6.

13. Kryukov F.D. Kray rodnoy [Motherland]. Donskaya volna, 1918, no. 12, p. 1.

14. Kryukov F.D. Rodimyy kray [Motherland]. Tikhiy Don. Nereshennaya zagadka russkoy literatury XX veka [Quiet Flows the Don. The Unsolved Mystery of Russian Literature of the 20th Century]. Available at: http://www.philol.msu.ru/ lex/td/?pid=012172\&oid= 042. (accessed December 20, 2015).
15. Kumov R.P. Stikhotvorenie v proze [The Poem in Prose]. Donskaya volna, 1918, no. 12, p. 2.

16. Litvinov V.V. Deti i grazhdanskaya voyna v Rossii [Children and Civil War in Russia]. Kultura narodov Prichernomorya, 2012, no. 228, pp. 78-87.

17. Mestnaya zhizn [Local Life]. Sever Dona, 1918, June 26 (no. 51).

18. Mestnaya zhizn [Local Life]. Sever Dona, 1918, June 29 (no. 54).

19. Mestnaya zhizn [Local Life]. Sever Dona, 1918, July 12 (no. 63).

20. Mestnaya zhizn [Local Life]. Sever Dona, 1918, July 20 (no. 70).

21. Mestnaya zhizn [Local Life]. Sever Dona, 1918, September 11 (no. 108).

22. Okruzhnoy krug, 12 iyunya [Circle of the Cossack District]. Sever Dona, 1918, June 13 (no. 41).

23. Okruzhnoy krug, 13 iyunya [Circle of the Cossack District]. Sever Dona, 1918, June 17 (no. 44).

24. O preobrazovanii chastnogo uchebnogo zavedeniya 1-go razryada, soderzhimogo P. Korotkovym v stanitse Ust-Medveditskoy v polnopravnuyu muzhskuyu gimnaziyu [On the Transformation of Private School of 1st Grade, Managed by P. Korotkov in the Village of UstMedveditskaya, into a Full-Fledged Gymnasium]. Rossiyskiy gosudarstvennyy istoricheskiy arkhiv [Russian State Historical Archive], F. 733. Department of People's Education List, Op. 168, D. 325.

25. Po stanitsam i khutoram, stanitsa Kletskaya [The Cossack Villages: Kletskaya Cossack Village]. Sever Dona, 1918, July 6 (no. 58).

26. Po stanitsam i khutoram, stanitsa UstKhoperskaya [The Cossack Villages: Ust-Khoperskaya Village]. Sever Dona, 1918, July 26 (no. 74).

27. Postanovlenie Soveta volnykh khutorov i stanits Ust-Medveditskogo okruga, № 25 [Resolution of the Council of Free Villages of Ust-Medveditsky District. no. 25]. Sever Dona, 1918, May 27 (no. 29).

28. Po hutoram i stanicam, stanica Kletskaja [In the Cossack villages, stanitsa Kletskay]. Sever Dona [North of the Don], 30 May 1918, no. 31.

29. Protokoly pedagogicheskogo soveta UstMedveditskogo realnogo uchilishcha, $1918 \mathrm{~g}$. [Protocols of Pedagogical Council of Ust-Medveditsky Secondary School, 1918]. Gosudarstvennyy arkhiv Volgogradskoy oblasti [State Archive of the Volgograd Region], F. 106. Ust-Medveditsky secondary school named after ataman M.I. Platov, Op. 1, D. 108.

30. Skachkov P. Donskaya letopis. 1923. № 1 [Don Chronicles. 1923. no. 1]. Donskaya armiya $v$ borbe $s$ bolshevikami [Don Army in the Fight Against the Bolsheviks]. Moscow, Tsentrpoligraf Publ., 2004, pp. 105-109.

31. Skachkov P. Otkrytoe pismo byvshemu predvoditelyu dvoryanstva, predsedatelyu syezda 


\section{ОТЕЧЕСТВЕННАЯ ИСТОРИЯ}

mirovykh sudey i imenuyushchemu sebya direktorom obshchestvennoy Ust-Medveditskoy kazach'ey gimnazii P.I. Korotkovu, 18 iyunya 1918 g. [The Open Letter to the Former Leader of the Nobility P.I. Korotkov, Chairman of the Congress of Justices of the Peace, Who Calls Himself Director of Public UstMedveditskaya Cossack Gymnasium]. Sever Dona, 1918, June 22 (no. 48).

32. Sychev V. Rol uchashcheysya molodezhi v dele vosstaniya v 1918 g. vUst-Medveditskom okruge Donskoy oblasti [The Role of Students in Revolt in 1918 in UstMedveditsky District of the Don Region]. Gosudarstvennyy arkhiv Rossiyskoy Federatsii [State
Archive of the Russian Federation], F. 5881, Collection of emigrants' certain documents and memoirs, Op. 2, D. 672.

33. Tekst vazhneyshikh postanovleniy, prinyatykh syezdom predstaviteley UstMedveditskogo okruga na zasedaniyakh $12-$ 14 iyunya $1918 \mathrm{~g}$. [The Text of the Most Important Resolutions Adopted by the Congress of Representatives of Ust-Medveditsky District at Sessions of June 12-14, 1918]. Filipp Mironov. (Tikhiy Don v 1917-1921 gg.) : dok. i materialy [Philip Mironov (Quiet Flows of the Don in 1917-1921). Documents and Materials]. Moscow, Mezhdunar. fond «Demokratiya», 1997, pp. 56-57.

\section{Information About the Author}

Svetlana Yu. Grechko, Postgraduate Student, Department of History of Russia, Volgograd State University; Teacher of History, Gymnasium no. 9 (Volgograd), Prosp. Universitetsky, 100, 400062 Volgograd, Russian Federation, svetlana_grechk@mail.ru, histrus@volsu.ru.

\section{Информация об авторе}

Светлана Юрьевна Гречко, аспирант кафедры истории России, Волгоградский государственный университет; учитель истории, МОУ гимназия № 9 г. Волгограда, просп. Университетский, 100, 400062 г. Волгоград, Российская Федерация, svetlana_grechk@mail.ru, histrus@,volsu.ru. 